\title{
Suitability assessment for oil palm (Elaeis guineensis) and coconut (Cocus nucifera) cultivation in coastal plain sands of South Southern Nigeria
}

\author{
Faith Ehinomhen Okunsebor ${ }^{*}$, Aigboghosa Samson Umweni, and Lucky Agbogun \\ Department of Soil Science and Land Management, Faculty of Agriculture, University of Benin \\ P.M.B 1154, Ugbowo Lagos Rd, Benin City, Edo State, Nigeria \\ *Corresponding author: faith.okunsebor@uniben.edu
}

\section{Article Info}

Received : $17^{\text {th }}$ April 2021

Revised : $11^{\text {th }}$ May 2021

Accepted: $01^{\text {st July } 2021}$

Keywords:

Isua, limitation, parametric, pedon, soil

\begin{abstract}
Some soils of coastal plain sands in South Southern Nigeria were assessed for oil palm and coconut cultivation. This research was carried out to evaluate the soils of the study area using rigid grid soil survey methodology at detailed scale. The study area (128.11 ha) was delineated into four soil mapping units based on soil type. A pedon was sunk in each mapping unit and described according to FAO. Three soil orders, including Entisols (Ahiara), Inceptisols (Kulfo) and Ultisols (Orlu), were identified. Parametric and limitation methods of land suitability evaluation were used. Major limitations to assessment were climate (mean annual temperatures) and soil physical properties (texture/structure). Aggregate suitability rating (both actual and potential) showed that Ultisols (pedons 3 and 4, covering 56.73 ha) was moderately suitable (S2) for Coconut and marginally suitable (S3) for oil palm, Inceptisols (pedon 2, covering 54.25 ha) was marginally suitable (S3) for coconut but not suitable (NS) for oil palm, and Entisols (Pedon 1 covering $17.13 \mathrm{ha}$ ) was not suitable (NS) for any of the crops. Thus, area with Entisols should not be used for cultivation of any of the crops due to major limitation in texture. Moreover, both assessment approaches captured the major limitations. Therefore, the use of any of the approaches employed in this study and for these crops becomes a matter of choice as both of them showed no major differences in the application of their procedures.
\end{abstract}

\section{INTRODUCTION}

Due to the drastic increase in world population, which is also a limiting factor to agricultural lands around the world, there is need for effective and efficient application of croplands in order to meet the increasing demand for food (Teklu, 2005; Behzad et al., 2009). Production of high-quality crops in an environmentally friendly, socially acceptable, and economically feasible way is the concept of sustainable agriculture (Addeo et al., 2001). Land suitability, therefore, measures how well the qualities of a land unit match the requirements of a particular form of land use (Food and Agriculture Organization, 1976).

Land suitability assessment is the process of estimating the potentials of agricultural land for diverse types of use on a sustainable basis (Peter and Umweni, 2020a). Determination of suitability of an area for agricultural purpose includes assessment of soil and other important factors like rainfall and the existing land management practices (Tenka and Balogun, 2019). Fertile soil is an essential factor on which the crop yield depends (Van Vliet et al., 2015), and it varies between locations. The need for land suitability evaluation before starting any agricultural project can't be over-emphasized as this neglect in the past has caused crops to be arbitrarily allocated to parts of the landscape where they are not ecologically suited, and this has led to massive failure of agricultural projects.

Oil palm and coconut are major commodities of international trade that help boost the economy of 
the producing countries as well as provide gainful employment for unemployed persons (Ahukaemere, 2018). Due to the tremendous advantages of oil palm and coconut in boosting both industrial and economic development, attempts have been made to increase their production especially in the SouthSouthern part of Nigeria where most soils are coastal plain sands. To achieve this goal, it is necessary to have comprehensive information on the biophysical resource and to identify the major limitations of the crop cultivation, thereby optimizing land use and increasing production (Oko-oboh et al., 2018). Knowledge of agricultural land resources will enable crop farmers to make adequate land use initiatives to improve and maintain high yield (Peter and Umweni, 2020b). Thus, the aim of this study was to assess the suitability of coastal plain sands of SouthSouthern part of Nigeria for oil palm and coconut cultivation using the limitation and parametric methods. Several approaches have been used for

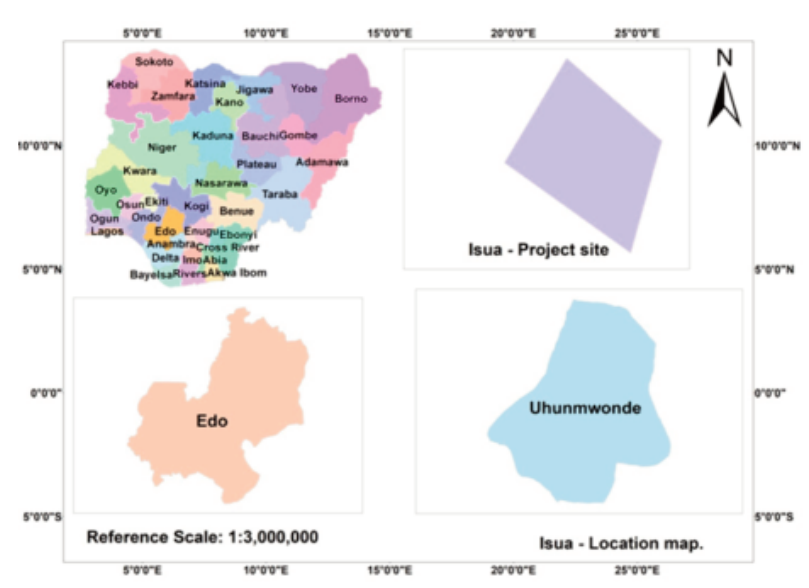

Figure 1. Location map of the study area

There are two distinct climatic seasons, consisting of rainy and dry seasons. The rainy season is between April and October with two weeks break in August, while the dry season lasts from November to April.

Generally, the soils of this area are red Ferrasols, derived from coastal plain sands (unconsolidated sands and sandy clay) and alluvial deposits (Umweni, 2007), which are the formations of sedimentary rock. The topography is a terrace $(0.3 \%$ to $9 \%)$ throughout the study area.

\section{Field studies}

Soil survey process was carried out using the land evaluation. However the guideline provided by Sys (1985) was used for evaluation of oil palm, and coconut was evaluated according to the guideline provided by Djaenudin et al. (2003), as modified by Oko-oboh et al. (2018).

\section{MATERIALS AND METHODS}

This study was conducted on a 128-hectare-land in Isua community (Uhunmwode Local Government Area) of Edo state. The site is located at a latitude of $6^{\circ} 18^{\prime} 24.08^{\prime \prime} \mathrm{N}$ and $6^{\circ} 18^{\prime} 30.56^{\prime \prime} \mathrm{N}$ and Longitude of 5 $57^{\prime} 12.23^{\prime \prime} \mathrm{E}$ and $5^{\circ} 57^{\prime} 58.3^{\prime \prime} \mathrm{E}$, as shown in Figures 1 and 2. Some of the crops grown include cassava, plantain, and oil palm. The area is characterized by a tropical climate, with an annual average rainfall amount of $1900 \mathrm{~mm}$, mean annual temperatures ranging from $23^{\circ} \mathrm{C}$ to $37^{\circ} \mathrm{C}$ and mean annual relative humidity ranging from $89 \%$ in the morning $(10.00$ AM) to $75 \%$ in the evening (4 PM) (NIFOR, 2020).

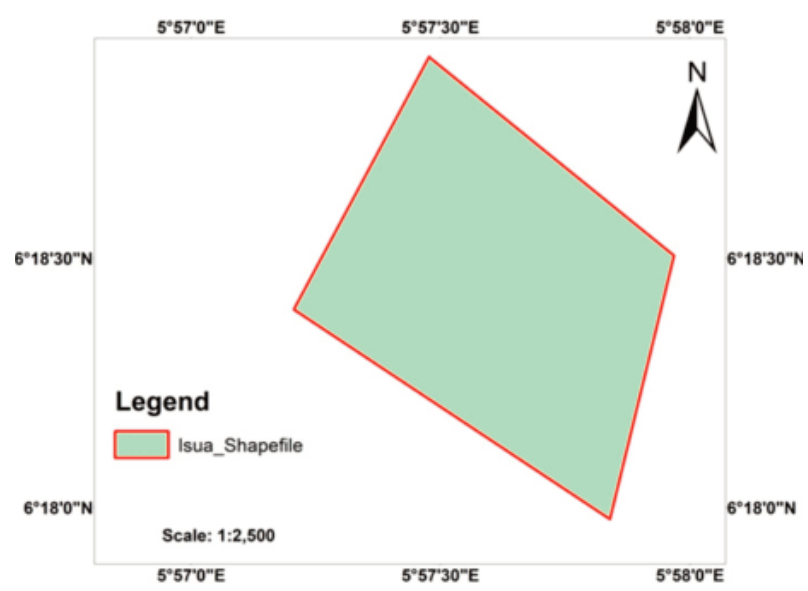

Figure 2. Shape of the study area

rigid grid method at a detailed scale on a 128.11 ha land. Traverses were cut at intervals of $100 \mathrm{~m}$ from pre-determined baseline with the transverses running in both vertical and horizontal directions, making a total of 10 traverses. Auger examinations were performed at $100 \mathrm{~m}$ apart along the traverses. The auger samples were observed at depth intervals of $0 \mathrm{~m}$ to $30 \mathrm{~cm}, 30 \mathrm{~cm}$ to $60 \mathrm{~cm}, 60 \mathrm{~cm}$ to $90 \mathrm{~cm}$, and $90 \mathrm{~cm}$ to $120 \mathrm{~cm}$ and appropriately described morphologically on the field (soil color, texture by feel, presence or absence of mottles, presence or absence of concretions, and so on). Areas with similar properties were put together to form the various 
soil mapping units, in which four mapping units were delineated. Each mapping unit was represented by a pedon that was described according to Food and Agriculture Organization (2006), and identified horizons/layers were sampled from bottom to top. The samples were properly bagged, labelled and taken to the laboratory for analysis. Analyses of the samples was carried out according to standard procedures. The coordinates of all profile pits were collected with the aid of a hand held geographical positioning system (GPS).

\section{Soil classification}

Soil classification was done with the guidelines provided by USDA soil taxonomy (Soil Survey Staff, 2014) and locally according to Ogunkunle (1983).

\section{Laboratory analysis}

Soil samples collected from each horizon were air-dried and sieved with a $2 \mathrm{~mm}$ sieve. The sieved samples were analyzed for some physical and chemical properties. Determination of particle size distribution was done by the hydrometer method

Table 1. Land and climatic characteristics for suitability classes for oil palm (Elaeis guineensis) cultivation

\begin{tabular}{|c|c|c|c|c|c|c|}
\hline $\begin{array}{l}\text { Land \& climatic } \\
\text { requirements }\end{array}$ & $\mathrm{S} 1_{1}$ & $\mathrm{~S}_{2}$ & S2 & S3 & N1 & N2 \\
\hline Score $\%$ & $95-100$ & $85-95$ & 85 & 60 & 40 & 25 \\
\hline \multicolumn{7}{|l|}{ Climate (c) } \\
\hline $\begin{array}{l}\text { Annual mean rainfall } \\
(\mathrm{mm})\end{array}$ & $>2,000$ & $1,700-2,000$ & $>1,450-1,700$ & $>1,250-1,450$ & - & $<1,250$ \\
\hline $\begin{array}{l}\text { Length of dry season } \\
\text { (months) }\end{array}$ & $\geq 1$ & $1-2$ & $2-3$ & $3-4$ & - & $>4$ \\
\hline $\begin{array}{l}\text { Annual mean } \\
\text { temperature }\left({ }^{\circ} \mathrm{C}\right)\end{array}$ & $>29$ & $27-29$ & $24-27$ & $22-24$ & - & $<22$ \\
\hline \multicolumn{7}{|l|}{ Topography (t) } \\
\hline Slope (S) (\%) & $0-4$ & $4-8$ & $8-16$ & $16-30$ & - & $>30$ \\
\hline \multicolumn{7}{|l|}{ Wetness (w) } \\
\hline Flooding & F0 & Fo & $\mathrm{F} 1$ & $\mathrm{~F} 2$ & - & F3 \\
\hline Drainage & Perfect & Mod-Well & - & Poor, aeric & $\begin{array}{c}\text { Poor } \\
\text { drainable }\end{array}$ & $\begin{array}{l}\text { Very poor, not } \\
\text { drainable }\end{array}$ \\
\hline \multicolumn{7}{|l|}{$\begin{array}{l}\text { Soil physical } \\
\text { characteristic (s) }\end{array}$} \\
\hline Texture & $\mathrm{Cl}, \mathrm{SCL}, \mathrm{L}$ & $\mathrm{CL}, \mathrm{SCL}, \mathrm{L}$ & $\mathrm{SCL}-\mathrm{L}$ & SCL-LFS & ANY & $\mathrm{S}, \mathrm{CS}$ \\
\hline Structure & Blocky & Blocky & - & - & - & $\begin{array}{l}\text { Massive single } \\
\text { grain }\end{array}$ \\
\hline $\begin{array}{l}\text { Coarse fragmentation } \\
\text { (vol.) within } 100 \mathrm{~cm} \mathrm{(z)}\end{array}$ & $>3-10$ & $10-15$ & $15-35$ & $35-55$ & - & $>55$ \\
\hline Depth $(\mathrm{cm})$ & $>100$ & $10-100$ & $50-90$ & $25-50$ & - & $<25$ \\
\hline \multicolumn{7}{|l|}{$\begin{array}{l}\text { Fertility characteristics } \\
\text { (f) }\end{array}$} \\
\hline $\operatorname{ECEC}\left(\right.$ meq. $\left.100 \mathrm{~g}^{-1}\right)$ & $>16$ & $15-16$ & $<15$ & - & - & - \\
\hline Base saturation (BS \%) & $>35$ & $20-35$ & $<20$ & - & - & - \\
\hline $\mathrm{pH}$ & $5.5-6.0$ & $5.5-6.0$ & $6.0-6.5$ & $6.5-7.0$ & $<4,>7.0$ & $<4,>7.0$ \\
\hline $\begin{array}{l}\text { Organic matterv }\left(\mathrm{g} \cdot \mathrm{kg}^{-1}\right. \\
\text { OC, } 0-15)\end{array}$ & $>15$ & $1.2-0.8$ & $<8$ & - & - & - \\
\hline $\begin{array}{l}\text { Salinity \% Alkalinity (N) } \\
\text { EC mmhos }\end{array}$ & $<1$ & $<1-2$ & $>2-3$ & $>3-4$ & $>4-8$ & $>38$ \\
\hline
\end{tabular}

Remarks: F0= no flooding, F1= 1-2 flooding months in $\geq$ ten years, $F 2=$ not more than $2-3$ flooding months in 5 years out of 10 , $F 3=2-4$ months every year, F4= more than 4 months in almost every year, Source: Sys (1985). 
Table 2. Land and climatic characteristics for suitability classes for coconut (Cocus nucifera)

\begin{tabular}{|c|c|c|c|c|}
\hline $\begin{array}{l}\text { Land \& climatic } \\
\text { requirements }\end{array}$ & S1 & $\mathrm{S} 2$ & S3 & $\mathrm{N}$ \\
\hline \multirow{2}{*}{$\begin{array}{l}\text { Annual mean } \\
\text { temperature }\left({ }^{\circ} \mathrm{C}\right)\end{array}$} & $25-28$ & $28-32$ & $32-35$ & $>35$ \\
\hline & & $23-25$ & $20-23$ & $<20$ \\
\hline \multicolumn{5}{|l|}{ Water availability (wa) } \\
\hline \multirow{2}{*}{$\begin{array}{l}\text { Annual mean rainfall } \\
(\mathrm{mm})\end{array}$} & $2000-3000$ & 1300-2000 & 1000-1300 & $<1000$ \\
\hline & & $3000-4000$ & $4000-5000$ & $>5000$ \\
\hline Dry months (months) & $0-2$ & $2-4$ & $4-6$ & $>6$ \\
\hline Humidity (\%) & $>60$ & $50-60$ & $<50$ & - \\
\hline \multicolumn{5}{|l|}{ Oxygen availability (oa) } \\
\hline Drainage & $\begin{array}{l}\text { Good } \\
\text { Moderate }\end{array}$ & Mod. Poor & $\begin{array}{l}\text { Poor. Mod. } \\
\text { Rapid }\end{array}$ & $\begin{array}{l}\text { Very poor. } \\
\text { Rapid }\end{array}$ \\
\hline \multicolumn{5}{|l|}{ Rooting condition (rc) } \\
\hline Soil texture & $\begin{array}{l}\text { Fine, slightly } \\
\text { fine, medium }\end{array}$ & Slightly fine & Very & Coarse \\
\hline $\begin{array}{l}\text { Volume of coarse } \\
\text { material (\%) }\end{array}$ & $<60$ & $15-35$ & $35-55$ & $>55$ \\
\hline Soil depth (cm) & $<140$ & 75-100 & $50-75$ & $<50$ \\
\hline Peat thickness (cm) & $>60$ & $60-140$ & $140-200$ & $>200$ \\
\hline \multicolumn{5}{|l|}{ Nutrient retention $(\mathrm{nr})$} \\
\hline CEC clay $\left(\mathrm{cmol} \mathrm{kg}^{-1}\right)$ & - & - & - & - \\
\hline Base saturation (\%) & $>20$ & $\leq 20$ & - & - \\
\hline \multirow[t]{2}{*}{$\mathrm{pH} \mathrm{H} \mathrm{H}_{2} \mathrm{O}$} & $5.2-7.5$ & $4.8-5.2$ & $>8.0$ & - \\
\hline & & $7.5-8.0$ & & \\
\hline Organic carbon (\%) & $>0.8$ & $\leq 0.8$ & & \\
\hline \multicolumn{5}{|l|}{ Toxicity (xc) } \\
\hline Salinity $\left(\mathrm{dS} . \mathrm{m}^{-1}\right)$ & $<12$ & $12-16$ & $16-20$ & $>20$ \\
\hline \multicolumn{5}{|l|}{ Erosion hazard (eh) } \\
\hline Slope (\%) & $<8$ & $8-16$ & $16-30$ & $>30$ \\
\hline Erosion hazard & Very low & Low moderate & Severe & Very severe \\
\hline \multicolumn{5}{|l|}{ Flooding hazard (h) } \\
\hline Flooding & F0 & - & $\mathrm{F} 1$ & $>\mathrm{F} 1$ \\
\hline \multicolumn{5}{|l|}{ Land preparation (Ip) } \\
\hline Surface stoniness (\%) & $<5$ & $5-15$ & $15-40$ & $>40$ \\
\hline Rock out crops (\%) & $<5$ & $5-15$ & $15-25$ & $>25$ \\
\hline
\end{tabular}

Remarks: $\mathrm{F} 0=$ no flooding, $\mathrm{F} 1=1-2$ flooding months in $\geq$ ten years, $\mathrm{F} 2=$ not more than 2-3 flooding months in 5 years out of $10, F 3=2-4$ months every year, $F 4=$ more than 4 months in almost every year, Source: Oko-oboh et al. (2018).

(Gee and Or, 2002) after the removal of organic matter content with hydrogen peroxide and dispersion with sodium hexametaphosphate (International Institute for Tropical Agriculture, 1979). Available phosphorus was determined according to Bray-1 method (Olsen and Sommers, 1982). Soil pH was determined with glass electrode $\mathrm{pH}$ meter in soil, with soil and water ratio of 1:1 (Mclean, 1982). Exchangeable Bases ( $\mathrm{Na}, \mathrm{K}, \mathrm{Ca}$, and $\mathrm{Mg}$ ) were extracted with neutral normal ammonium acetate $\left(\mathrm{NH}_{4} \mathrm{OAC}\right.$ at $\left.\mathrm{pH} 7.0\right), \mathrm{Na}$ and $\mathrm{K}$ were determined by flame photometer, while $\mathrm{Ca}$ and $\mathrm{Mg}$ were determined by atomic absorption spectrophotometer (Thomas, 1982). Total Nitrogen was determined by Macro Kjedhal method (Bremner, 
1996). Exchangeable Acidity determination was done by titration method (Anderson and Ingram, 1993). Walkley Black method was used to determine Organic Carbon (Page, 1982). Effective Cation Exchange Capacity (ECEC) was obtained by the summation of exchangeable bases and exchangeable acidity (Tan, 1996). Calculation of base saturation was done by dividing the sum of exchangeable bases $(\mathrm{Na}, \mathrm{K}, \mathrm{Ca}$ and $\mathrm{Mg}$ ) by ECEC and multiplying the quotient by 100 .

\section{Land suitability evaluation}

Land suitability evaluation was done using both parametric and limitation method. Limitation method was based on Food and Agriculture Organization (1976) frame work for rain fed agriculture and guidelines provided by Sys (1985) for oil palm (Table 1) and Djaenudin et al. (2003) as modified by Okooboh et al. (2018) for coconut (Table 2). For limitation method, pedons were placed in suitability classes by comparing their land qualities and characteristics (climate, topography, wetness, soil physical properties, and topography) with the guideline. The suitability class of a pedon (aggregate suitability) is indicated by the most limiting (poorest) characteristics of that pedon. This was done in accordance with the principle of the law of minimum, which states that performance is always determined by the least favorable factor or plant nutrient in the lowest supply (Food and Agriculture Organization, 1984).

For parametric method, scores were given to the quality of each pedon, and suitability was calculated as index of productivity using the square root model of Storie (1976).

$\mathrm{IPC}=\mathrm{AV}(\mathrm{B} / 100 * \mathrm{C} / 100 * \mathrm{D} / 100 * \mathrm{E} / 100) \ldots(1)$ (Sys, 1985)
(c) (t)
(w)
(s)
(f)

Where $A$ is the overall least characteristic rating, $\mathrm{c}=$ climate, $\mathrm{t}=$ topography, $\mathrm{w}=$ wetness, $\mathrm{s}=$ slope, $\mathrm{f}=$ fertility.

Using this method, each characteristic was first rated as follows: no limitation $=100-85$ (S1); moderate limitation $=84-60(\mathrm{~S} 2)$; severe limitation= 59-40 (S3); very severe limitation $=39-0(\mathrm{~N})$. The index of productivity for each pedon was expressed from the rating of each characteristic of the land qualities of each group, using the lowest rating. Index of productivity was rated into classes as stated by Ogunkunle (1993): highly suitable (S1) = 100-75; moderately suitable $(\mathrm{S} 2)=74-50$; marginally suitable $(\mathrm{S} 3)=49-25$; non suitable $(\mathrm{N})=24-0$.

\section{RESULTS AND DISCUSSION}

\section{Physical and chemical properties of the soils}

Table 3 shows the physical and chemical properties of the soil in the study area. Sand fraction was dominant in pedon 1 and in all the surface horizons of pedons 2, 3 and 4. It varied from 859 g. $\mathrm{kg}^{-1}$ to 940 g. kg ${ }^{-1}$ in pedon 1 and 834 g. kg ${ }^{-1}$ to 859 g. kg ${ }^{-1}$ in pedons 2, 3 and 4 . The dominance of sand fraction in surface horizon could be linked to the parent material (coastal plain sands) from which the soils were derived (Peter and Umweni, 2020b). Silt fraction ranged from $10 \mathrm{~g} \cdot \mathrm{kg}^{-1}$ to $51 \mathrm{~g} . \mathrm{kg}^{-1}$ in all the horizons.

Table 3. Soil physical and chemical properties of the study area

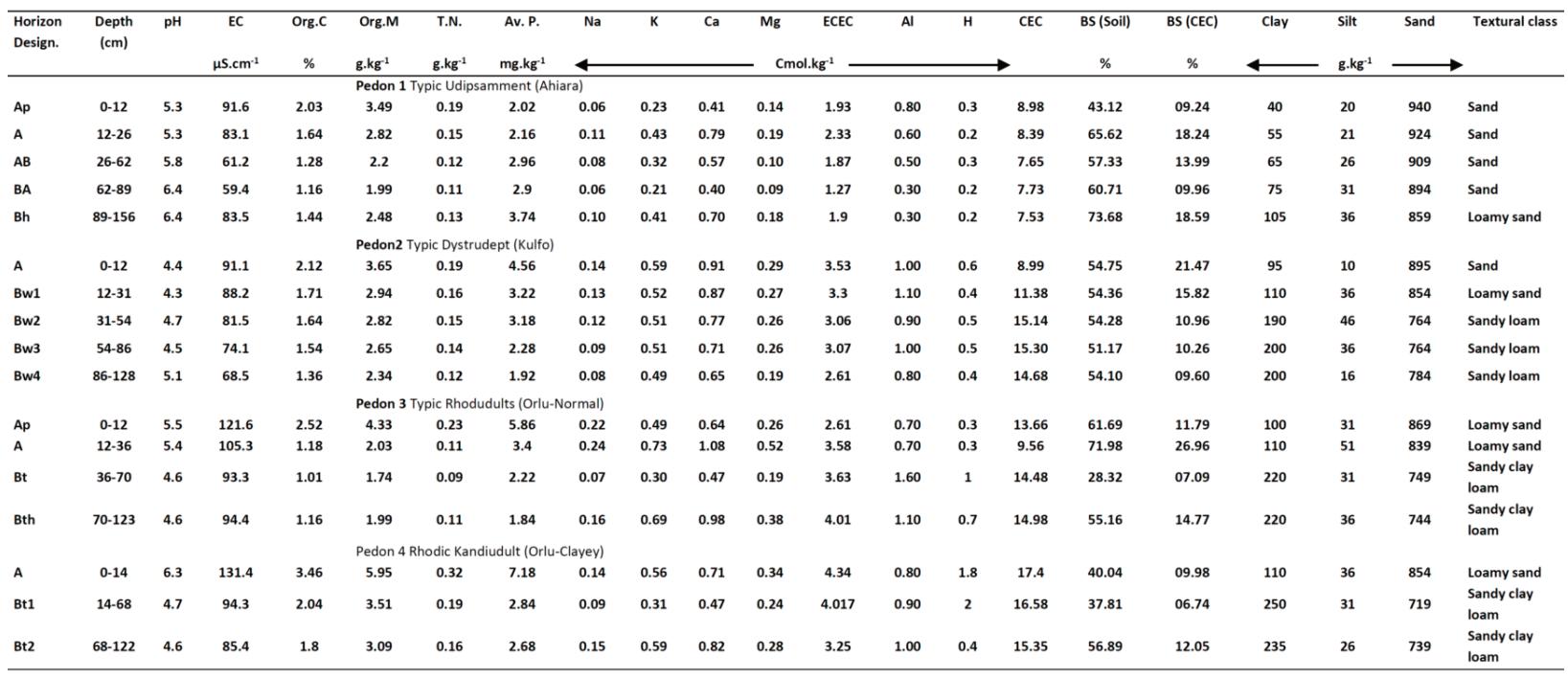


The low silt content could be due to high intensity of leaching in the study area. Clay fraction of particle size varied from $40 \mathrm{~g} . \mathrm{kg}^{-1}$ to $250 \mathrm{~g} . \mathrm{kg}^{-1}$. Clay content increased with increase in depth, suggesting active eluviation and illuviation processes. Soil $\mathrm{pH}$ ranged from 5.3-6.4 in pedon 1, 4.3-5.1 in pedon 2, 4.6-5.5 in pedon 3, and 4.6-6.3 in pedon 4. Organic carbon ranged from $1.01 \%$ to $3.46 \%$ in all the pedons, and it decreased irregularly from top to bottom of the profile. The low organic carbon content is in line with the findings of Peter and Umweni (2021). Total nitrogen was low, ranging from $0.09 \%$ to $0.19 \%$ in all the pedons. This could be as a result of the high rainfall amount in the study area (Peter and Umweni, 2020a).

\section{Soil classification}

Three soils were classified as Typic UdipsammentAhiara (Pedon 1), Typic Dystrudept-Kulfo (pedon 2), Typic Rhodudults-Orlu (pedon 3), and Rhodic Kandiudult-Orlu Clayey (pedon 4) by USDA soil taxonomy (Soil Survey Staff, 2014) and locally by Ogunkunle (1983).

\section{Limitation approach}

Suitability assessment for oil palm (Elaeis guineensis) and coconut (Cocos nucifera) was done using the guidelines provided by Djaenudin et al. (2003) as modified by Oko-oboh et al. (2018).

\section{Climate}

According to the guidelines provided by Okooboh et al. (2018) for coconut and Sys (1985) for oil palm, the annual rainfall of the study area is 1900 mm (NIFOR, 2020), classified in S1 (highly suitable) for coconut and S2 (moderately suitable) for oil palm cultivation. The mean annual temperature of the study site ranges from $23^{\circ} \mathrm{C}$ to $37^{\circ} \mathrm{C}$, with a mean of $30^{\circ} \mathrm{C}$, classified in $\mathrm{S} 1$ (highly suitable) for oil palm and S3 (marginally suitable) for coconut. The length of dry months was considered moderately suitable for both crops (oil palm and coconut). Meanwhile, the relative humidity (75\% to $89 \%$ ) was classified as highly suitable for coconut cultivation.

\section{Topography}

The topography of the study area was highly suitable (S1) in the mapping units 1 (0.3\% to $1.9 \%)$, 2 (3\% to $5.2 \%$ ), and 4 (3.5 \% to $5 \%$ ), while mapping unit 3 (7.1\% to $9 \%$ ) was moderately suitable (S2) for oil palm (Sys 1985). However, mapping unit 1 was moderately suitable for coconut, while other mapping units were highly suitable (Oko-oboh et al., 2018).

\section{Wetness}

The result obtained from Table 4 showed that the study area has no flooding problem. It is well drained, and the results obtained from table show that it is classified in $\mathrm{S}_{1}$ (Highly suitable) for both crops according to the guidelines.

\section{Soil physical characteristics}

The soil depth was greater than $100 \mathrm{~cm}$ in all the pedons, which according to the guidelines (Tables 2 and 3 ) is highly suitable for cultivation of oil palm and coconut. Soil texture of pedon 1 was not suitable for both crops (S-LS). Pedon 2 (S-SL) was not suitable for oil palm but was moderately suitable for coconut. Pedons 3 and 4 (LS-SCL) were highly suitable (S1) for coconut but moderately suitable (S3) for oil palm. Soil structure in pedon 1 was permanently not suitable (N2), with single grain crumbs, while the structure in pedons 2, 3 and 4 ranged from single grain crumbs to sub-angular blocky (Oko-oboh et al., 2018; Sys, 1985).

\section{Fertility characteristics}

This refers to the chemical fertility of the soil with reference to the properties that are easily altered (actual) as well as the requirements for potential fertility as it affects the production of oil palm and coconut.

\section{Potential soil fertility}

Potential fertility refers to the chemical properties that are not easily altered. They include CEC, base saturation, $\mathrm{pH}$ and organic matter content (Ogunkunle, 1993). These properties were adequate in all pedons.

The guidelines by Oko-oboh et al. (2018) for coconut and Sys (1985) for oil palm showed that base saturation, which ranged from $28.32 \%$ to $73.68 \%$, in all pedons placed both crops in suitability class of S1 (highly suitable). $\mathrm{pH}$ (4.6-6.4) ranged from strongly acid to slightly acid, which is a situation that is expected of acid sands (soils developed from coastal plain sand), pedon 1 was considered highly suitable (S1), while pedons 2,3 , and 4 were moderately suitable for both crops according to the guidelines. In Pedon 1, organic carbon/organic matter $(0 \mathrm{~cm}$ to 30 
$\mathrm{cm}$ ) ranging from $1.18 \%$ to $3.46 \%$ / $20.30 \mathrm{~g} \cdot \mathrm{kg}^{-1}$ to $59.50 \mathrm{~g} . \mathrm{kg}^{-1}$ rated all pedons in suitability class of S1 (highly suitable) for both crops. EC ranging from $1.27 \mathrm{cmol} . \mathrm{kg}^{-1}$ to $4.34 \mathrm{cmol} . \mathrm{kg}^{-1}$ for all pedons rated the study area suitability class of S2 (moderately suitable) for both oil palm and coconut according to the guidelines by Oko-oboh et al. (2018) and Sys (1985).

\section{Current soil fertility}

This refers to the chemical fertility that puts into consideration, the properties that are easily altered, and the requirements for potential fertility as it affects the production of oil palm and coconut (Ogunkunle, 1993).

The suitability evaluation of each pedon for oil palm and coconut cultivation by limitation method (both current and potential) shown in Table 4 showed that pedon 1 (Entisols-17.13 ha representing $13.37 \%$ of

Table 4. Summary of suitability evaluation for all pedons (Limitation method)

\begin{tabular}{|c|c|c|c|c|c|c|c|c|}
\hline \multirow{2}{*}{ Land characteristics } & \multicolumn{2}{|c|}{ Pedon 1} & \multicolumn{2}{|c|}{ Pedon 2} & \multicolumn{2}{|c|}{ Pedon 3} & \multicolumn{2}{|c|}{ Pedon 4} \\
\hline & Oil palm & Coconut & Oil palm & Coconut & Oil palm & Coconut & Oil palm & Coconut \\
\hline \multicolumn{9}{|l|}{ Climate (c) } \\
\hline $\begin{array}{l}\text { Annual mean rainfall } \\
(\mathrm{mm})\end{array}$ & $\mathrm{S} 1_{1}$ & S1 & $\mathrm{S} 1_{1}$ & S1 & $\mathrm{S} 1_{1}$ & S1 & $\mathrm{S} 1_{1}$ & S1 \\
\hline $\begin{array}{l}\text { Length of dry season } \\
\text { (months) }\end{array}$ & $\mathrm{S} 2$ & $\mathrm{~S} 2$ & S2 & S2 & $\mathrm{S} 2$ & $\mathrm{~S} 2$ & $\mathrm{~S} 2$ & $\mathrm{~S} 2$ \\
\hline $\begin{array}{l}\text { Annual mean } \\
\text { temperature }\left({ }^{\circ} \mathrm{C}\right)\end{array}$ & $\mathrm{S} 1_{1}$ & S3 & $\mathrm{S} 1_{1}$ & S3 & $\mathrm{S} 1_{1}$ & S3 & $\mathrm{S} 1_{1}$ & S3 \\
\hline Relative Humidity (\%) & & S1 & & S1 & & S1 & & $\mathrm{S} 1$ \\
\hline \multicolumn{9}{|l|}{ Topography (t) } \\
\hline Slope (\%) & $\mathrm{S} 2$ & $\mathrm{~S} 2$ & S2 & S1 & $\mathrm{S}_{12}$ & S1 & $\mathrm{S} 1_{1}$ & S1 \\
\hline \multicolumn{9}{|l|}{ Wetness (w) } \\
\hline Flooding & $\mathrm{S} 1_{1}$ & & $\mathrm{~S} 1_{1}$ & & $\mathrm{~S} 1_{1}$ & & $\mathrm{~S} 1_{1}$ & \\
\hline Drainage & $\mathrm{S} 1_{1}$ & S1 & $\mathrm{S} 1_{1}$ & S1 & $\mathrm{S} 1_{1}$ & S1 & $\mathrm{S} 1_{1}$ & S1 \\
\hline \multicolumn{9}{|l|}{$\begin{array}{l}\text { Soil physical } \\
\text { characteristics (s) }\end{array}$} \\
\hline Texture & N2 & $\mathrm{N}$ & N1 & $\mathrm{S} 2$ & S3 & S1 & S3 & S1 \\
\hline Structure & N2 & & N2 & & S2 & & $\mathrm{S} 2$ & \\
\hline Coarse fragment & - & - & - & - & - & - & - & - \\
\hline Soil depth & $\mathrm{S} 1_{1}$ & S1 & $\mathrm{S} 1_{1}$ & S1 & $\mathrm{S} 1_{1}$ & S1 & $\mathrm{S} 1_{1}$ & S1 \\
\hline \multicolumn{9}{|l|}{ Soil fertility (f) } \\
\hline CEC $\left(\mathrm{cmol}^{\mathrm{kg}} \mathrm{kg}^{-1}\right)$ & $\mathrm{S} 2$ & & S2 & & $\mathrm{S} 2$ & & $\mathrm{~S} 2$ & \\
\hline Base saturation (\%) & $\mathrm{S} 1_{1}$ & S1 & $\mathrm{S} 1_{1}$ & S2 & $\mathrm{S} 1_{1}$ & $\mathrm{~S} 2$ & $\mathrm{~S} 1_{1}$ & $\mathrm{~S} 2$ \\
\hline Soil ph & $S 1_{1}$ & S1 & $\mathrm{S} 1_{1}$ & & $\mathrm{~S} 1_{1}$ & & $\mathrm{~S} 1_{1}$ & \\
\hline Organic matter & $\mathrm{S} 1_{1}$ & S1 & $\mathrm{S} 1_{1}$ & S1 & $\mathrm{S} 1_{1}$ & S1 & $\mathrm{S} 1_{1}$ & S1 \\
\hline Salinity & - & - & - & - & - & - & - & - \\
\hline Ec & $\mathrm{S} 1_{1}$ & - & $\mathrm{S} 1_{1}$ & - & $\mathrm{S} 1_{1}$ & - & $\mathrm{S} 1_{1}$ & - \\
\hline \multicolumn{9}{|c|}{ Aggregate suitability class } \\
\hline Actual suitability & N2 (s) & $N(s)$ & N1 (s) & S3 (c) & S3 (s) & S3 (c) & S3 (s) & S3 (c) \\
\hline Potential suitability & N2 (s) & $N(s)$ & $\mathrm{N} 1(\mathrm{~s})$ & S3 (c) & S3 (s) & $\mathrm{S} 3$ (c) & S3 (s) & $\mathrm{S} 3$ (c) \\
\hline Size (ha) & \multicolumn{2}{|c|}{17.13} & \multicolumn{2}{|c|}{54.25} & \multicolumn{2}{|c|}{25.27} & \multicolumn{2}{|c|}{31.46} \\
\hline$\%$ Coverage & \multicolumn{2}{|c|}{13.37} & \multicolumn{2}{|c|}{42.35} & \multicolumn{2}{|c|}{17.73} & \multicolumn{2}{|c|}{24.56} \\
\hline
\end{tabular}


Table 5. Summary of suitability evaluation for all pedons (Parametric approach)

\begin{tabular}{|c|c|c|c|c|c|c|c|c|}
\hline \multirow{2}{*}{ Land characteristics } & \multicolumn{2}{|c|}{ Pedon 1} & \multicolumn{2}{|c|}{ Pedon 2} & \multicolumn{2}{|c|}{ Pedon 3} & \multicolumn{2}{|c|}{ Pedon 4} \\
\hline & Oil palm & Coconut & Oil palm & Coconut & Oil palm & Coconut & Oil palm & Coconut \\
\hline \multicolumn{9}{|l|}{ Climate (c) } \\
\hline $\begin{array}{l}\text { Annual mean rainfall } \\
(\mathrm{mm})\end{array}$ & $100\left(S 1_{1}\right)$ & $100(S 1)$ & $100\left(S 1_{1}\right)$ & $100(\mathrm{~S} 1)$ & $100\left(S 1_{1}\right)$ & $100(S 1)$ & $100\left(S 1_{1}\right)$ & $100(\mathrm{~S} 1)$ \\
\hline $\begin{array}{l}\text { Length of dry season } \\
\text { (months) }\end{array}$ & $75(S 2)$ & 75 (S2) & $75(S 2)$ & $75(S 2)$ & $75(S 2)$ & 75 (S2) & 75 (S2) & 75 (S2) \\
\hline $\begin{array}{l}\text { Annual mean } \\
\text { temperature }\left({ }^{\circ} \mathrm{C}\right)\end{array}$ & $100\left(S 1_{1}\right)$ & $60(S 3)$ & $100\left(S 1_{1}\right)$ & $60(\mathrm{~S} 3)$ & $100\left(S 1_{1}\right)$ & $60(S 3)$ & $100\left(S 1_{1}\right)$ & $60(S 3)$ \\
\hline Relative Humidity (\%) & - & 100 (S1) & - & $100(\mathrm{~S} 1)$ & - & 100 (S1) & - & $100(\mathrm{~S} 1)$ \\
\hline \multicolumn{9}{|l|}{ Topography (t) } \\
\hline Slope (\%) & 75 (S2) & 75 (S2) & 75 (S2) & $100(\mathrm{~S} 1)$ & $\mathrm{S}_{2}$ & 100 (S1) & $100\left(S 1_{1}\right)$ & $100(\mathrm{~S} 1)$ \\
\hline \multicolumn{9}{|l|}{ Wetness (w) } \\
\hline Flooding & $100\left(S 1_{1}\right)$ & - & $100\left(S 1_{1}\right)$ & - & $100\left(S 1_{1}\right)$ & - & $100\left(S 1_{1}\right)$ & - \\
\hline Drainage & $100\left(S 1_{1}\right)$ & 100 (S1) & $100\left(S 1_{1}\right)$ & $100(\mathrm{~S} 1)$ & $100\left(S 1_{1}\right)$ & 100 (S1) & $100\left(S 1_{1}\right)$ & $100(\mathrm{~S} 1)$ \\
\hline \multicolumn{9}{|l|}{$\begin{array}{l}\text { Soil physical } \\
\text { characteristics (s) }\end{array}$} \\
\hline Texture & N2 & $\mathrm{N}$ & N1 & 75 (S2) & $60(S 3)$ & 100 (S1) & $60(\mathrm{S3})$ & $100(\mathrm{~S} 1)$ \\
\hline Structure & N2 & & N2 & & 75 (S2) & & 75 (S2) & \\
\hline Coarse fragment & - & - & - & - & - & - & - & - \\
\hline Soil depth & $100\left(S 1_{1}\right)$ & $100(\mathrm{~S} 1)$ & $100\left(S 1_{1}\right)$ & $100(\mathrm{~S} 1)$ & $100\left(S 1_{1}\right)$ & $100(\mathrm{~S} 1)$ & $100\left(S 1_{1}\right)$ & $100(\mathrm{~S} 1)$ \\
\hline \multicolumn{9}{|l|}{ Soil fertility (f) } \\
\hline CEC $\left(\mathrm{cmol} . \mathrm{kg}^{-1}\right)$ & 75 (S2) & - & 75 (S2) & - & 75 (S2) & - & 75 (S2) & - \\
\hline Base saturation (\%) & $100\left(S 1_{1}\right)$ & $100(\mathrm{~S} 1)$ & $100\left(S 1_{1}\right)$ & 75 (S2) & $100\left(S 1_{1}\right)$ & $75(S 2)$ & $100\left(S 1_{1}\right)$ & 75 (S2) \\
\hline Soil ph & $100\left(S 1_{1}\right)$ & $100(\mathrm{~S} 1)$ & $100\left(S 1_{1}\right)$ & & $100\left(S 1_{1}\right)$ & & $100\left(S 1_{1}\right)$ & \\
\hline Organic matter & $100\left(S 1_{1}\right)$ & $100(\mathrm{~S} 1)$ & $100\left(S 1_{1}\right)$ & $100(\mathrm{~S} 1)$ & $100\left(S 1_{1}\right)$ & $100(\mathrm{~S} 1)$ & $100\left(\mathrm{~S}_{1}\right)$ & $100(\mathrm{~S} 1)$ \\
\hline Salinity & - & - & - & - & - & - & - & - \\
\hline Ec & $100\left(S 1_{1}\right)$ & - & $100\left(S 1_{1}\right)$ & - & $100\left(S 1_{1}\right)$ & - & $100\left(S 1_{1}\right)$ & - \\
\hline
\end{tabular}

\section{Aggregate suitability class}

\begin{tabular}{|c|c|c|c|c|}
\hline Actual suitability & $15.59(\mathrm{~N}) \quad 13.42(\mathrm{~N})$ & $15.59(\mathrm{~N}) 45.00(\mathrm{~S} 3)$ & 28.73 (S3) 51.96 (S2) & 44.25 (S3) 51.96 (S2) \\
\hline Potential suitability & $15.59(\mathrm{~N}) \quad 13.42(\mathrm{~N})$ & $15.59(\mathrm{~N}) 45.00(\mathrm{~S} 3)$ & 28.73 (S3) 51.96 (S2) & 44.25 (S3) 51.96 (S2) \\
\hline Size (ha) & 17.13 & 54.25 & 25.27 & 31.46 \\
\hline$\%$ Coverage & 13.37 & 42.35 & 17.73 & 24.56 \\
\hline
\end{tabular}

Remarks: Aggregate suitability scores: S1= 100-75, highly suitable; S2= 74-50, moderately suitable; S3= 49-25, marginally suitable; $\mathrm{N}=24-0$, not suitable.

the research area) was not suitable (N) for cultivation of oil palm and coconut due to limitation in soil physical properties (texture and structure). Pedons 3 and 4 (Ultisols- 56.73 ha representing $44.28 \%$ of the study area) were marginally suitable (S3) for both crops because of limitation in climate (mean annual temperature-coconut) and soil physical properties (soil texture-oil palm). Pedon 2 (Inceptisols54.25 ha representing $42.35 \%$ of study area) was not suitable $(\mathrm{N})$ for oil palm because of limitation in texture and structure but marginally suitable (S3) for coconut because of limitation in climate.

The suitability evaluation of each pedon for oil palm and coconut cultivation by parametric method (current and potential) shown in Table 5, showed that pedon 1 (Entisols-17.13 ha representing $13.37 \%$ of the study area) was not suitable ( $\mathrm{N}$ ) for cultivation of oil palm and coconut. Pedon 2 (Inceptisols-54.25 
Table 6. Aggregate suitability ratings of the mapping units for oil palm (Elaeis guineensis) and coconut (Cocus nucifera) by both parametric and limitation approaches)

\begin{tabular}{|c|c|c|c|c|c|c|c|c|c|c|}
\hline \multirow[t]{2}{*}{ Pedon } & \multirow[t]{2}{*}{ USDA Classification } & \multirow{2}{*}{$\begin{array}{c}\text { Areal } \\
\text { extent }(\mathrm{Ha})\end{array}$} & \multicolumn{2}{|c|}{$\begin{array}{l}\text { Limitation } \\
\text { (actual) }\end{array}$} & \multicolumn{2}{|c|}{$\begin{array}{l}\text { Limitation } \\
\text { (potential) }\end{array}$} & \multicolumn{2}{|c|}{$\begin{array}{l}\text { Parametric } \\
\text { (actual) }\end{array}$} & \multicolumn{2}{|c|}{$\begin{array}{l}\text { Parametric } \\
\text { (potential) }\end{array}$} \\
\hline & & & Oil palm & Coconut & Oil palm & Coconut & Oil palm & Coconut & Oil palm & Coconut \\
\hline 1 & $\begin{array}{l}\text { Typic Udipsamment } \\
\text { (Ahiara) }\end{array}$ & 17.13 & N2 (s) & $N(s)$ & N2 (s) & $N(s)$ & $\begin{array}{l}15.59 \\
(\mathrm{~N})\end{array}$ & $\begin{array}{c}13.42 \\
(\mathrm{~N})\end{array}$ & $\begin{array}{l}15.59 \\
(\mathrm{~N})\end{array}$ & $\begin{array}{l}13.42 \\
(\mathrm{~N})\end{array}$ \\
\hline 2 & $\begin{array}{l}\text { Typic Dystrudept } \\
\text { (Kulfo) }\end{array}$ & 54.25 & N1 (s) & S3 (c) & $\mathrm{N} 1$ (s) & S3 (c) & $\begin{array}{l}15.59 \\
(N)\end{array}$ & $\begin{array}{l}45.00 \\
(S 3)\end{array}$ & $\begin{array}{l}15.59 \\
(N)\end{array}$ & $\begin{array}{l}45.00 \\
(\mathrm{~S} 3)\end{array}$ \\
\hline 3 & $\begin{array}{l}\text { Typic Rhodudults } \\
\text { (Orlu) }\end{array}$ & 25.27 & S3 (s) & S3 (c) & S3 (s) & S3 (c) & $\begin{array}{c}28.73 \\
(\mathrm{~S} 3)\end{array}$ & $\begin{array}{l}51.96 \\
(\mathrm{~S} 2)\end{array}$ & $\begin{array}{c}28.73 \\
(\mathrm{~S} 3)\end{array}$ & $\begin{array}{l}51.96 \\
(S 2)\end{array}$ \\
\hline 4 & $\begin{array}{l}\text { Rhodic Kandiudult } \\
\text { (Orlu) }\end{array}$ & 31.46 & S3 (s) & S3 (c) & S3 (s) & S3 (c) & $\begin{array}{c}44.25 \\
\text { (S3) }\end{array}$ & $\begin{array}{l}51.96 \\
(\mathrm{~S} 2)\end{array}$ & $\begin{array}{l}44.25 \\
(\mathrm{~S} 3)\end{array}$ & $\begin{array}{l}51.96 \\
(\mathrm{~S} 2)\end{array}$ \\
\hline
\end{tabular}

ha representing $42.35 \%$ of study area) was not suitable $(\mathrm{N})$ for oil palm but it was marginally suitable (S3) for coconut. Pedons 3 and 4 (Ultisols-56.73 ha representing $44.28 \%$ of the study area) were marginally suitable (S3) for oil palm and moderately suitable for coconut cultivation.

Summary of land suitability assessment for the study area is as shown in Table 6. Major limitations encountered were climate (mean annual temperature) and soil physical properties (texture and structure) which are difficult to amend (Peter and Umweni, 2020b). Hence, aggregate suitability ratings for current and potential suitability ratings did not vary.

The disparity in aggregate suitability ratings by both approaches (parametric and limitation) indicates differences in the approaches. While only a characteristic that is not suitable places a pedon in the not suitable class (N) under limitation approach, parametric approach takes all the characteristics into consideration. Thus, the parametric approach is truly an aggregate of the whole, in reaching the final suitability class (Oko-oboh et al., 2018).

\section{CONCLUSIONS}

Parametric approach revealed that 56.73 ha (Ultisols-pedons 3 and 4) representing $44.28 \%$ of the entire research area was moderately suitable (S2) for coconut (both potentially and currently) but marginally suitable for oil palm cultivation. A total of 54.25 ha (Inceptisols-pedon 2) representing $42.35 \%$ of study area was marginally suitable for coconut cultivation but not suitable for oil palm cultivation, while 17.13 ha (Entisols-pedon 1) representing $13.37 \%$ of the study area was not suitable for both crops. Major limitations encountered were climate and soil physical characteristics. Area represented by pedon 1 (Entisols-17.13 ha) should not be used for cultivation of any of the crops. Moreover, both assessment approaches captured the major limitations. Therefore, the use of any of the approaches employed in this study and for these crops becomes a matter of choice as both of them show no major differences in the application of their procedures.

\section{REFERENCES}

Addeo, G.G., Guastadisegni, G., and Pisante, M. (2001). Land and water quality for sustainable and precision farming. World Congress on Conservation Agriculture, Madrid, pp.34-38.

Ahukaemere, C.M. (2018). Suitability evaluation of some soils of South-Eastern Nigeria for oil palm (Elaeis guineensis) and cocoa (Theobroma cacao) cultivation. Int'l Journal of Agric. and Rural Dev., 21(1), pp. 3355-3361.

Anderson, J.M. and Ingram, J.S.I. (1993). Tropical soil biology and fertility: a handbook of methods, $2^{\text {nd }}$ ed. Wallingford: CAB International, pp. 221.

Behzad, M., Albaji, M., Papan, P., Nasab, B.S., Naseri, A.A., and Bavi, A. (2009). Qualitative evaluation of land suitability for principal crops in the Gargar Region, Khuzestan Province, Southwest Iran. Asian Journal of Plant Sciences, 8(1), pp. 28-34.

Bremner, J.M. (1996). Nitrogen total. In: Sparks, D.L., ed., Methods of soil analysis. Part 3, Chemical Methods. $2^{\text {nd }}$ ed. Madison: Soil Science Society of America, pp. 1085-1125.

Djaenudin, D., Marwan, H., Subagjo, H., and Hidayat A. 
Petunjuk teknis evaluasi lahan untuk komoditas pertanian. $1^{\text {st }}$ ed. Bogor: Balai Penelitian Tanah, pp. 132.

Gee, G.W. and Or, D. (2002). Particle size analysis. In: Dane J.H. and Topp, G.C., eds., Methods of Soil Analysis Part 4. Physical Methods. Madison: Soil Science Society of America, pp. 225-293.

Food and Agriculture Organization. (2006). Guidelines for soil description. $4^{\text {th }}$ ed. Rome: AGLS, FAO, pp. 21-65

Food and Agriculture Organization. (1984). Guidelines of land evaluation for rainfed agriculture. Soils Bulletin No. 52. Rome: FAO, pp.191

Food and Agriculture Organization. (1976). A framework for land evaluation. FAO Soils Bulletin 52. $1^{\text {st }}$ ed. Rome: FAO, pp.79.

International Institute for Tropical Agriculture-IITA (1979). Selected methods for soil and plant analysis. $3^{\text {rd }}$ ed. Ibadan: International Institute for Tropical Agriculture, pp. 34

Mclean, E.O. (1982). Soil pH and lime requirement. In: Page, A.L. ed., Methods of Soil Analysis Part 2, Chemical and Microbiological Properties. Madison: American Society of Agronomy, Soil Science Society of America, pp. 199-224.

NIFOR, (2020). Weather data (Temperature, rainfall, relative humidity): 1993-2020. Nigerian Institute for Oil Palm Research Main Station, Benin City, Nigeria.

Ogunkunle, A.O. (1993). Soil in land suitability evaluation: an example with oil palm in Nigeria. Soil Use and Management, 9(1), pp. 35-40.

Ogunkunle, A.O. (1983). Updating the classification of acid sand soils with particular reference to the soils of NIFOR main station. Journal of the Nigerian Institute for Oil Palm Research, 6, pp. 234-255.

Oko-oboh, E., Senjobi, B. A., Ajiboye, G. A., Oviasogie, P. O. and Awanlemhen, B. E. (2018) Suitability assessment of soils of NIFOR Sub-station Ohosu Edo State for oil palm (Elaeis guineensis) and coconut (Cocus nucifera) cultivation. Nigerian Journal of Soil Science, 28(1), pp. 218-228.

Olsen, S.R. and Sommers, L.E.(1982). Phosphorus. In: Page, A.L., Miller, R.H., and Keeney, D.R., eds., Methods of Soil Analysis Part 2. Madison, Wisconsin: American Society of Agronomy, pp 15-72.

Page, A.L. (Ed). (1982). Methods of soil analysis. $2^{\text {nd }}$ ed. Agronomy No. 9. Part 2. Madison, Wisconsin: American Society of Agronomy.
Peter, K.D. and Umweni, A.S. (2021). Evaluation of land suitability for citrus cultivation in Khana Local Government Area of Rivers State, Southern Nigeria. IImu Pertanian (Agricultural Science), 6(1), pp. 1-9.

Peter, K.D. and Umweni, A.S. (2020a). Morphological and physical properties of development from coastal plain sands and alluvium in Khana Local Government Area of Rivers State, Southern Nigeria. African Journal of Sustainable Agricultural Development, 1(1), pp 1-9

Peter, K.D. and Umweni, A.S. (2020b). Characterization and classification of soils developed from coastal plain sands and alluvium in Khana Local Government Area of Rivers State, Southern Nigeria. Direct Research Journal of Agriculture and Food Science, 8(7), pp 246-253

Soil Survey Staff. (2014). United States Department of Agriculture keys to soil taxonomy. $12^{\text {th }}$ ed. Washington DC: National Resource Conservation Service, US Dept. of Agriculture, pp. 353.

Storie, R. E. (1976). Storie index soil rating. Special Publication Division of Agricultural Science, University of California, Berkeley, 3, pp. 203231.

Sys, C. (1985). Land evaluation part 1-111 publication No. 7. Place de champs de mars 5, Biote 57, 1050 Bruxelles: The General Administration of Cooperative Development, pp. 247.

Tan, K.H. (1996). Soil sampling, preparation and analysis. $1^{\text {st }}$ ed. Madison Avenue, New York: Mercel Dekker Inc., pp. 127.

Teklu, E.J. (2005). Land preparation methods and soil quality of a vertisol area in the central highlands of Ethiopia. PhD Thesis. Universitat Hohenheim.

Tenka, P. E., and Balogun, B. O. (2019). Land suitability for cocoa production in Idanre, Ondo State, Nigeria. Journal of Agricultural Biotechnology and Sustainable Development, 12(2), pp. 19-33

Thomas, G.W. (1982). Exchangeable cation. In: Page, A.L. et. al., eds., Methods of Soil Analysis Part 2, Agronomy Monograph, 9. $2^{\text {nd }}$ ed. Madison, Wisconsin: ASA and SSSA, pp.159-165.

Umweni, A.S. (2007). Irrigation capability evaluation of some sedimentary soils In Edo State, Nigeria. Thesis. University of Ibadan, Nigeria.

Van Vliet, J.A., Slingerland, M., Giller, E.G. (2015). Mineral nutrition of cocoa. Wageningen: Plant Production System Group, Wageningen University, pp. 70. 